\author{
Anna Lipka \\ Uniwersytet Ekonomiczny w Katowicach \\ e-mail: anna.lipka@ue.katowice.pl \\ ORCID: 0000-0002-0849-0935
}

\title{
POMIAR RYZYKA NIESPÓJNOŚCI CYFROWEGO WIZERUNKU PRACODAWCY
}

DOI: $10.15611 /$ pn.2020.5.08

JEL Classification: 015, M16

(C) 2020 Anna Lipka

Ten artykut jest rozpowszechniany w otwartym dostępie na licencji Creative Commons Uznanie autorstwa-Użycie niekomercyjne-Bez utworów zależnych 3.0 PL (http://creativecommons.org/ licenses/by-nc-nd/3.0/)

Cytuj jako: Lipka, A. (2020). Pomiar ryzyka niespójności cyfrowego wizerunku pracodawcy. Prace Naukowe Uniwersytetu Ekonomicznego we Wrocławiu, 64(5).

Streszczenie: Opracowanie o charakterze metodycznym zorientowano na cel, jakim jest opis źródeł i negatywnych skutków niespójności cyfrowego wizerunku pracodawcy. Następnie przypisano je do poszczególnych rodzajów ryzyka personalnego oraz zaproponowano sposób oceny ich poziomu dla warunków deficytów i - dla porównania - nadwyżek kadrowych na rynku pracy. Uwzględniono przy tym macierz oceny ryzyka według D. Baccariniego oraz propozycje metodyczne J.E. Martina i P.-F. Heaulme'a. W ten sposób znaleziono odpowiedź na problem badawczy sformułowany w postaci pytania: jak mierzyć poziom ryzyka niespójności cyfrowego wizerunku pracodawcy, biorąc pod uwagę sytuację popytowo-podażową na rynku pracy?

Słowa kluczowe: ryzyko niespójności, cyfrowy wizerunek pracodawcy, pomiar ryzyka personalnego, zależność ryzyka od relacji popytowo-podażowych.

\section{Wstęp}

Wizerunek pracodawcy (employer branding) to jego obraz ,W oczach pracowników" (wizerunek wewnętrzny) oraz potencjalnych pracowników (wizerunek zewnętrzny). Ma on znaczenie dla ryzyka rekrutacyjnego i ryzyka kosztów pracy, gdyż według badań [Minchington 2018] firmy cieszące się opinią dobrego pracodawcy są w stanie przyciągnąć najwartościowszych pracowników za średnio o 20\% niższe wynagrodzenie niż firmy ze słabą marką.

Ze względu na rewolucję przemysłową 4.0. i odpowiadające jej trendy dotyczące kapitału ludzkiego (transformacja w cyfrowe organizacje i cyfrowych pracowników), 
a także oczekiwania ze strony najmłodszej generacji pracowników ważny jest cyfrowy wizerunek pracodawcy dotyczący zastosowania w każdym obszarze funkcjonalnym, także w human resources, technologii informacyjno-komunikacyjnych (information and communication technology - ICT). Należy zadbać o jego spójność (koherencję), której brak może mieć różne źródła i konsekwencje.

Przedmiotem szczególnej uwagi w niniejszym opracowaniu uczyniono objęcie wirtualizacją różnych procesów personalnych. Wobec braku odpowiednio dokładnej definicji w literaturze przedmiotu dotyczącej ryzyka koherencji analizowanego wymiaru employer branding przyjęto, że ryzyko niespójności cyfrowego wizerunku pracodawcy oznacza rozbieżności między obrazem w pełni nowoczesnej technologicznie organizacji a realiami jej funkcjonowania. Prezentacje kategorii i metod pomiaru ryzyka (wizerunkowego) pracodawcy w literaturze przedmiotu (zob. [Backhaus, Tikoo 2004; Hausmann, Williams 2014; Lorek 2011; Wojtaszczyk 2012]) pomijają ten wymiar bądź nie są wystarczające. Nie da się ponadto bezpośrednio do celów pomiaru ryzyka niespójności cyfrowego wizerunku pracodawcy zastosować ani przeglądowych, ani wspomagających, ani scenariuszowych, funkcyjnych, kontroli i oceny, statystycznych czy pozostałych metod i technik oceny ryzyka normy PN-EN 31010:2010 (por. też ISO 9001:2015). Istnieje zatem luka badawcza. Celem opracowania jest zaproponowanie sposobu pomiaru ryzyka niespójności cyfrowego wizerunku pracodawcy. Zastosowano następujące postępowanie badawcze:

- zidentyfikowano (w oparciu o literaturę przedmiotu) źródła i konsekwencje ryzyka niespójności cyfrowego wizerunku pracodawcy (które to ryzyko operacjonalizuja),

- przyporządkowano je do klasyfikacji ryzyka personalnego,

- zidentyfikowano metody, których połączenie pozwoli mierzyć analizowane ryzyko,

- dokonano egzemplifikacji ich użycia w celu określenia wpływu dwóch diametralnie różnych sytuacji na rynku pracy na poziom tego ryzyka (gdyż w dostępnej literaturze przedmiotu [Kobi 2002] zawarte są jedynie teoretyczne rozważania na ten temat).

\section{Charakterystyka źródeł ryzyka niespójności cyfrowego wizerunku pracodawcy i ich implikacji}

Cyfrowy wizerunek pracodawcy, jeśli jest odpowiednio wyrazisty, sygnalizuje typ kultury organizacyjnej oraz pozwala zaszeregować firmę do grona firm innowacyjnych. Jednocześnie może być wykorzystywany - w ramach AIDA (A - attenion (uwaga), I - interest (zainteresowanie), D (desire (pragnienie), A (action (działanie)) - do przyciagania kandydatów, gdyż obecnie możliwość pracy w nowoczesnym technologicznie środowisku uatrakcyjnia ofertę pracy i jest jednym z silniejszych motywatorów. $\mathrm{Z}$ wykorzystaniem cyfrowego wizerunku mogą być budowane EVP (employee value proposition), czyli unikatowe wartości dla pracowników o charakterze funkcjonalnym, ekonomicznym czy psychologicznym. Korzyści z tym związa- 
ne kojarzone są bowiem przez potencjalnych kandydatów do pracy z takimi ważnymi dla nich zaletami, jak większy komfort pracy (związany $\mathrm{z}$ wyposażeniem stanowiska pracy), większa swoboda wyboru miejsca i czasu, a tym samym - wykonywanie sensowniejszej pracy (a prace pozbawione, w odczuciu pracobiorców, sensu nie generują dobrostanu [Graeber 2020]) oraz możliwość łączenia życia zawodowego i pozazawodowego. ICT ułatwiają logistykę rekrutacyjną, zajmując kandydatom mniej czasu. Umożliwiają pozostawanie online z potencjalnym pracodawcą i mogą dostarczać pracobiorcom pozytywnych wrażeń (candidate experience). Błędy dotyczące powyższych kwestii podwyższają ryzyko rekrutacyjne, odnoszone także do osób, które mają być zatrudniane w firmie nie po raz pierwszy (można zatem mówić o ryzyku ERM - employee relationship management).

Ryzyko to jest podwyższone, gdy uatrakcyjnianie oferty pracy (stanowiska pracy i wynagrodzenia) nie jest wystarczająco silnie łączone z nowoczesnym modelem dostarczania doświadczeń (np. w postaci aplikacji cyfrowych) kandydatowi związanych z pracą w nowoczesnej technologicznie firmie. Można wtedy mówić o niespójności koncepcji marketingu-mix w odniesieniu do cyfrowej organizacji, w której pracobiorca ma być interesariuszem.

Zagrożeniem dla koherencji cyfrowego wizerunku organizacji jest rezygnacja z zastosowania nagrań wideo celem zorientowania się przez kandydatów, czy dysponują prezentowanymi nań umiejętnościami. Utraconą szansę stanowi też niezastąpienie tradycyjnych prób pracy oprogramowaniem stymulującym pracę, a także zaniechanie:

- grywalizacji podczas rekrutacji (dostarczającej pozytywnych wrażeń),

- metod ilościowych (np. wielokryterialnej techniki korzyści) podwyższających sprawność rekrutacji i stanowiących przejaw walki z nepotyzmem w trakcie przyjmowania do pracy,

- tworzenia raportów rekrutacyjnych w czasie rzeczywistym.

Czynnikiem ryzyka w tworzeniu omawianego wizerunku jest też niereagowanie na negatywne wpisy o firmie w przestrzeni internetowej. Mogą one w różny sposób szkodzić reputacji firmy (np. poprzez dyskredytację tezauryczną, kwestionująca osiagnięcia firmy np. w promowaniu i sprzedaży nowych produktów na nowych rynkach), negatywnie wpływając na jej kapitał zarówno ludzki, jak i kliencki. Jednocześnie należy obniżać ryzyko pozyskiwania informacji o kandydatach z osobistych profili na mediach społecznościowych, ograniczając się do informacji ogólnodostępnych, publicznych (z mediów branżowych i opiniotwórczych).

Internetowe ogłoszenia rekrutacyjne promujące firmę pod kątem jej nowoczesności (w tym - usieciowienia) jako czynnika motywującego do podjęcia w niej pracy powinny nie tylko wykorzystywać odpowiednią infografikę, ale być sformułowane przez profesjonalistów sprawnych językowo i przestrzegających zasad poprawności obyczajowej, a także potrafiących sprostać innym wymogom kultury języka [Markowski 2019], takim jak estetyka słowa czy grzeczność językowa. Ta pierwsza może być operacjonalizowana m.in. stopniem ekspresywności, nienadużywaniem modnych 
słów, prostotą składniową czy unikaniem utartych wyrażeń językowych, a druga - jasnością prezentacji firmy zgłaszającej potrzebę zatrudnieniową, stosowaniem potocyzmów czy użyciem słów podkreślających podmiotowość kandydatów do pracy. Szczególnie ważne jest wykorzystanie zwrotów obrazujących komfort pracy i dokonanie trafnego w danej sytuacji wyboru spośród szerokiego spektrum kreatywnych środków językowych, które kształtowałyby pozytywny odbiór pracodawcy jako firmy wykorzystującej w praktyce nowoczesne rozwiązania ICT.

Ważny jest przy tym - z uwagi na zagrożenie spadkiem motywacji i niską lojalnością już po zatrudnieniu - autentyzm ogłoszeń rekrutacyjnych, tj. spójność między nimi a rzeczywistością organizacyjną w postaci odpowiednio wynagradzanej pracy w zdygitalizowanym środowisku (inaczej: niewystapienie dysonansu poznawczego typu candidate experience - employee experience).

Niezbędny element koherencji cyfrowego wizerunku pracodawcy stanowi dysponowanie przez wszystkich pracowników firmy kompetencjami cyfrowymi (digital competences), umożliwiającymi pozyskiwanie, ocenianie, przetwarzanie oraz przesyłanie informacji drogą internetową. Chodzi o określony, minimalny poziom umiejętności cyfrowych, np. „podstawy pracy z komputerem”, „podstawy pracy w sieci”, ,przetwarzanie tekstów” czy ,,arkusze kalkulacyjne”, do doskonalenia których wszyscy pracownicy mieliby jednakowy dostęp (w sensie ewentualnego wsparcia merytorycznego i/lub finansowego). Musi mu towarzyszyć jednakowy poziom przeszkolenia w zakresie RODO oraz jego stosowanie w praktyce, co powinno być przedmiotem oceniania pracowników (w ramach kryteriów behawioralnych stosowanych w koncepcji oceniania typu „transformacja“). Przedmiotem tegoż oceniania powinna być też jakość współpracy w ramach zespołów wirtualnych, których cechą jest wysoka efektywność dzięki stałemu pozostawaniu w kontakcie [Leung, Zheng 2012, s. 202-208], np. podczas realizacji projektów.

Spójność cyfrowego wizerunku pracodawcy może też doznać uszczerbku w przypadku niejednolitego nasycenia wszystkich działów oraz procesów w organizacji innowacjami technologiczno-komunikacyjnymi. Wpływać to może negatywnie na (międzypokoleniową) wymianę wiedzy i umiejętności pomiędzy pracownikami, a także na niemożność doświadczania podobnie pozytywnych odczuć i wrażeń związanych z pracą $\mathrm{w}$ przyjaznym technologicznie środowisku. Niejednakowy poziom cyfryzacji działów organizacji mógłby spowodować znaczne utrudnienia (np. w pozyskiwaniu danych) $\mathrm{w}$ działach mniej technologicznie zaawansowanych.

Ponadto niska cyfrowość niektórych działów opóźnia przepływ informacji w całej firmie oraz możliwość ujednoliconego oceniania uzyskiwanych wyników, wpływając na efektywność funkcjonowania całego systemu i różnice efektywnościowe dotyczące różnych komórek organizacyjnych (np. przygotowujących raporty tylko w wersjach papierowych lub wyłącznie elektronicznych), a w konsekwencji na odpływ pracowników i klientów. Czynnikiem ryzyka są zwłaszcza różnice w statusie organizacyjnym pracowników w zróżnicowany sposób „wzmocnionych” technologicznie (augumented workforce) [Deloitte Global Human Capital Trends 
2018]. Istnienie tych różnic - poprzez konflikty na tym tle - wpływać może negatywnie na wizerunek wewnętrzny pracodawcy. Ponadto pozostawanie niektórych działów/pracowników w trybie offline powoduje różnice w zakresie ich kontrolowania, co może stanowić czynnik demotywujący do pracy. Na wizerunek wewnętrzny negatywnie wpływa też brak zakładki „kariera”, w której zamieszczone są propozycje stanowisk pracy uwypuklające ich nasycenie ICT. Konieczność korzystania $\mathrm{z}$ „metod analogowych”, tj. pozbawienie „cyfrowej opieki” może ponadto generować utrudnienia podczas realizacji przedsięwzięć rozwojowych.

Spójność cyfrowego wizerunku pracodawcy oznacza jednolitość rodzaju oprogramowania w całej firmie ( $\mathrm{tj}$. niedopuszczenie do współfunkcjonowania systemów

Tabela 1. Potencjalne obszary wirtualizacji zarządzania kapitałem ludzkim w firmie

\begin{tabular}{|c|c|}
\hline Operacyjny szczebel zarządzania & Taktyczny i strategiczny szczebel zarządzania \\
\hline $\begin{array}{l}\text { Analizy profili kwalifikacyjnych } \\
\text { Nawiązywanie relacji i komunikowanie } \\
\text { się z kandydatami do pracy } \\
\text { Przeprowadzanie procesu pozyskiwania } \\
\text { pracowników włącznie z wdrażaniem } \\
\text { do pracy poprzez dostarczanie, dostępnych } \\
\text { w każdym miejscu i czasie, materiałów } \\
\text { Uatrakcyjnianie (pod względem treści } \\
\text { i formy) ogłoszeń rekrutacyjnych poprzez } \\
\text { benchmarking internetowych ofert pracy } \\
\text { Wspomaganie procesu tworzenia } \\
\text { zespołów } \\
\text { Wsparcie bieżących ocen przydatności do } \\
\text { pracy, identyfikacji potrzeb szkoleniowych } \\
\text { Wsparcie ilościowych metod } \\
\text { wspomagających realokacje pracowników } \\
\text { Wspomaganie ocen efektywności szkoleń } \\
\text { Wspieranie analiz zaangażowania w pracę } \\
\text { oraz zadowolenia z pracy } \\
\text { Weryfikacja potrzeb rozszerzania form } \\
\text { płac o nowoczesne formy } \\
\text { Elektroniczny system zarządzania } \\
\text { czasem pracy, wyjazdami służbowymi, } \\
\text { wynagradzaniem } \\
\text { Wspomaganie procesu oceniania } \\
\text { pracowników i raportowania w tym } \\
\text { zakresie } \\
\text { Raportowanie dotyczące procesu } \\
\text { odchodzenia z pracy }\end{array}$ & $\begin{array}{l}\text { Analizy zmian stanu i struktury zatrudnienia } \\
\text { w powiązaniu z jego dynamiką } \\
\text { Analizy zmian wartości kapitału ludzkiego } \\
\text { Analizy poliwalencji (możliwego zastępowania } \\
\text { się pracowników) na bazie dyferencjacji profili } \\
\text { kwalifikacyjnych } \\
\text { Prognozy dotyczące wakatów i zapotrzebowania na } \\
\text { pracowników } \\
\text { Prognozy zmian wymagań pracy na kluczowych } \\
\text { stanowiskach w firmie } \\
\text { Kreowanie wizerunku firmy w mediach } \\
\text { społecznościowych } \\
\text { Analizy rynku pracy } \\
\text { Wsparcie stosowania metod analizy strategicznej } \\
\text { Analizy zmian ogólnego stopnia przydatności do } \\
\text { pracy w firmie } \\
\text { Wsparcie metod zarządzania sensem pracy } \\
\text { Wspomaganie badań kultury organizacyjnej } \\
\text { Symulacje dotyczące wynagradzania w przypadku } \\
\text { jego zmian } \\
\text { Symulacje dotyczące tempa i rodzaju zwolnień } \\
\text { i odejść z pracy } \\
\text { Badanie wpływu zmian czynników motywacyjnych } \\
\text { na retencję zatrudnienia } \\
\text { Analizy wartości wnoszonych przez rekomendacje } \\
\text { pracowników } \\
\text { Analizy dotyczące „pracowników-bumerangów“ } \\
\text { (powracających do firmy po pewnym czasie) } \\
\text { Analizy kosztów ERM } \\
\text { Analizy zmian poziomu ryzyka personalnego } \\
\text { Analizy dotyczace nroiektów z zakresu HR }\end{array}$ \\
\hline
\end{tabular}

Źródło: zaktualizowane na podstawie [Lipka 1996, s. 28-108]. 
różnych generacji i opóźnień z konwersją). W przypadku wprowadzania zmian w tym zakresie wskazane jest informowanie o tym interesariuszy, gdyż brak jasnego przekazu może podwyższać ryzyko wizerunkowe pracodawcy. Czynnikiem ryzyka jest też niestosowanie mobilnych aplikacji, które opóźnia realizację procesów wewnętrznych, np. możliwość zdalnej naprawy błędów w systemie w czasie przebywania poza siedzibą firmy. Takim czynnikiem jest też niezapewnienie możliwości korzystania z chmur danych odciążających serwery z wielogigabajtowych plików oraz niezabezpieczenie funkcjonowania wewnętrznych komunikatorów, za pomocą których można się porozumiewać „bez odchodzenia od biurka”, efektywniej wykorzystując swój czas pracy (także dzięki wskazówkom udzielonym przez inne osoby).

Ważnym czynnikiem generującym ryzyko niekoherencji jest ponadto ograniczenie się w wirtualizacji procesów do rekrutacji (mimo ważności tego zagadnienia [Verhoeven 2019]) i ewentualnie rozwoju bez wykorzystania możliwości wirtualizacji innych obszarów zarządzania kapitałem ludzkim, i to nie tylko na operacyjnym szczeblu zarządzania (tab. 1).

Ważne jest też - celem ograniczenia ryzyka - badanie efektywności różnych opcji inwestowania $\mathrm{w}$ cyfrowy wizerunek firmy wewnątrz i na zewnątrz organizacji. Trudna mierzalność niektórych efektów nie powinna być powodem zaniechania badań.

\section{Propozycja pomiaru ryzyka niekoherencji cyfrowego wizerunku pracodawcy}

Opisane źródła ryzyka na tle niespójności cyfrowego wizerunku pracodawcy da się przypisać czterem wyróżnianym w literaturze przedmiotu [Kehrel, Kehrel 2011, s. 38] rodzajom ryzyka personalnego przedstawionym $\mathrm{w}$ tab. 2 , tj. ryzyku rekrutacyjnemu (od 1 do 5), motywacyjnemu (od 6 do 11), lojalnościowemu (od 12 do 17), uzupełnionym o ryzyko efektywnościowe (od 18 do 23).

Do określenia w sposób przymiotnikowy poziomu ryzyka zastosowano, oparta na negatywnej koncepcji ryzyka, macierz według D. Baccariniego [2001], która określa ten poziom w oparciu o prawdopodobieństwo wystapienia negatywnych zdarzeń i rozmiar ich potencjalnych negatywnych skutków (tab. 2). Choć jest to ocena arbitralna, zorientowana na ilustrację metodyki postępowania, to jednak wzięto w niej pod uwagę:

- bardzo duże straty związane z trudnościami rekrutacyjnymi w sytuacji ssania (przewagi popytu nad podażą pracy) na rynku pracy i ich niewystępowanie w sytuacji ciśnienia (przewagi podaży nad popytem);

- niską obecnie medianę stażu pracy u jednego pracodawcy;

- dużą wagę przywiązywaną obecnie (zwłaszcza przez milenialsów) do określonych motywatorów na rynku pracy oraz ich niespełnienie jako poważną przesłankę odejść z firmy;

- zależność efektywności pracy i funkcjonowania firmy na rynku ogólnym nie tylko od sytuacji na rynku pracy. 


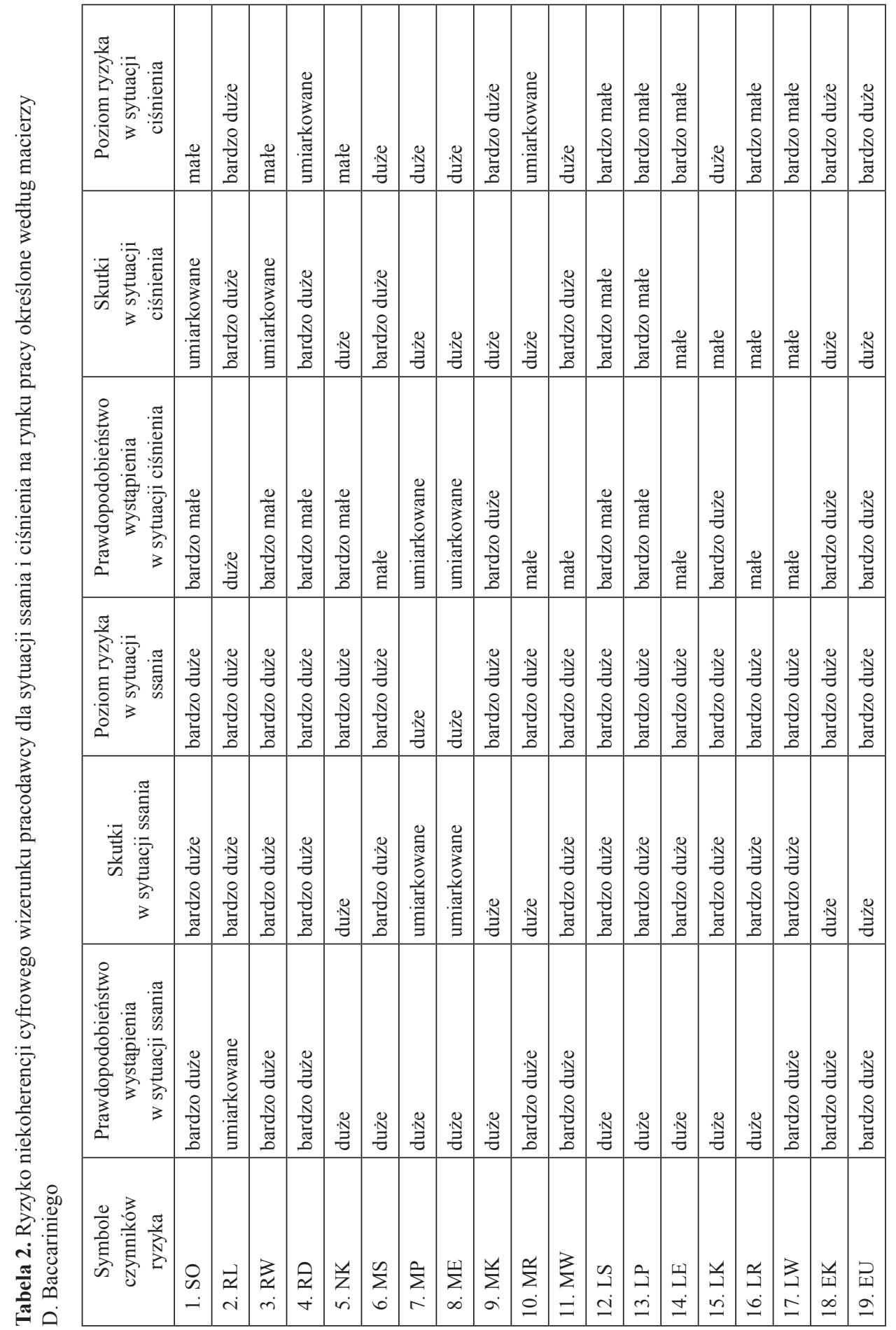




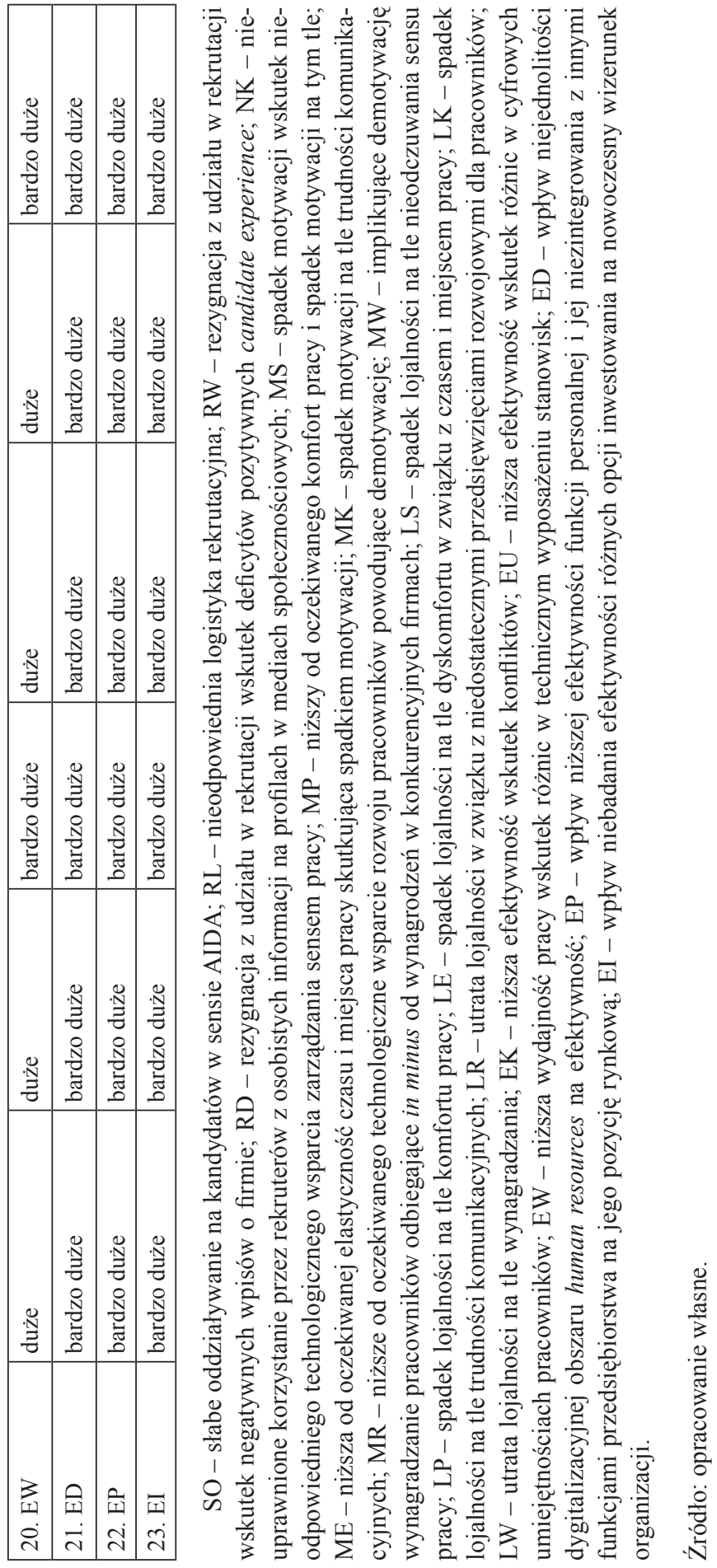


Jak wynika z tab. 2, ryzyko dla sytuacji ssania na rynku pracy jest co najmniej duże, a najczęściej bardzo duże. Natomiast dla sytuacji ciśnienia na rynku pracy byłoby głównie dla ryzyka efektywnościowego i ryzyka logistyki rekrutacyjnej bardzo duże, dla pozostałych zaś rodzajów ryzyka - najczęściej bardzo małe.

Chcąc przekształcić powyższe przymiotnikowe oceny ryzyka w skwantyfikowane ryzyko, sięgnięto do macierzy oceny ryzyka według J.E. Martina i P.-F. Heaulme’a, która zawiera taką samą liczbę poziomów ryzyka co tabela według D. Baccariniego (tab. 3).

Tabela 3. Wynik transformacji macierzy oceny ryzyka według D. Baccariniego w macierz oceny dla wybranych* poziomów ryzyka

\begin{tabular}{|l|l|c|}
\hline \multicolumn{1}{|c|}{$\begin{array}{c}\text { Prawdopodobieństwo } \\
\text { wystąpienia }\end{array}$} & \multicolumn{1}{|c|}{ Negatywne skutki } & Kwantyfikacja** \\
\hline Bardzo małe & bardzo małe & $(0,5)$ \\
\hline Małe & małe & $(1,5)$ \\
\hline Bardzo małe & umiarkowane & $(3,5)$ \\
\hline Bardzo małe & duże & $(3,0)$ \\
\hline Małe & umiarkowane & $(3,5)$ \\
\hline Bardzo duże & małe & $(4,0)$ \\
\hline Umiarkowane & umiarkowane & $(4,0)$ \\
\hline Bardzo małe & bardzo duże & $(5,0)$ \\
\hline Małe & bardzo duże & $(5,0)$ \\
\hline Duże & umiarkowane & $(5,0)$ \\
\hline Umiarkowane & duże & $(7,0)$ \\
\hline Duże & duże & $(7,0)$ \\
\hline Umiarkowane & bardzo duże & $(8,0)$ \\
\hline Duże & bardzo duże & $(8,0)$ \\
\hline Bardzo duże & duże & $(9,0)$ \\
\hline Bardzo duże & bardzo duże & \\
\hline
\end{tabular}

*Występujących w tab. 2.

** Na podstawie danych zaczerpniętych z [Martin, Heaulme 1998].

Źródło: opracowano na podstawie danych zaczerpniętych z [Martin, Heaulme 1998].

$\mathrm{Z}$ wyznaczonych na tej podstawie poziomów poszczególnych rodzajów ryzyka wynika, że:

- jest ono najwyższe $(9,0)$ dla efektywności strategicznej $(E D, E P, E I)$ i to niezależnie od sytuacji na rynku pracy;

- jest takie samo dla efektywności operacyjnej, niezależnie także od tej sytuacji;

- jest ono wyższe dla ryzyka rekrutacyjnego, motywacyjnego i lojalnościowego dla sytuacji ssania niż dla sytuacji ciśnienia na rynku pracy;

- w każdym z powyższych przypadków jest wysokie. 


\section{Zakończenie}

W opracowaniu wyodrębniono z ryzyka pracodawcy ryzyko niespójności jego cyfrowego wizerunku, mającego rosnące znaczenie w warunkach rewolucji przemysłowej 4.0. Zidentyfikowano jego źródła i implikacje jako podstawy pomiaru ryzyka. Okazało się, że źródła te można przyporządkować do klasyfikacji ryzyka personalnego według takich autorów, jak A. Kehrel, U. Kehrel [2011]. Pokazano, że możliwy jest pomiar ryzyka niespójności cyfrowego wizerunku pracodawcy z wykorzystaniem połączenia dwóch różnych metod oceny ryzyka - według D. Baccariniego oraz J.E. Martina i P.-F. Heaulme'a. Ponadto wykazano, że relacje popytowo-podażowe na rynku pracy $\mathrm{w}$ zróżnicowany sposób wpływają na poszczególne składowe (cząstkowe rodzaje) analizowanego ryzyka. Uzyskane wartości pomiaru (wszystkie powyżej 5.0) wskazują na konieczność stosowania metod prewencji tegoż ryzyka, np. w postaci kontrolowania komentarzy na temat firmy dotyczących inwestycji w dobrostan pracowników. Powyższą problematykę warto kontynuować, zwłaszcza w odniesieniu do jakże aktualnych warunków poszerzania zakresu pracy zdalnej [Breuer 2014, s. 245-260] ze względu na „ogólnoświatową przestrzeń zagrożeń" i ,społeczeństwo globalnego ryzyka” [Beck 2012, s. 7-8]. W tych bowiem warunkach ujawnia się autentyzm cyfrowego wizerunku pracodawcy.

\section{Literatura}

Baccarini D., 2001, Risk management Australia style - theory vs practice, Project Management Institute, https://www.pmi.org/learning/library/implementing-theory-practise-risk-management-7890 (27.04.2020).

Backhaus K.B., Tikoo S., 2004, Conceptualizing and researching employer branding, Career Development International, no. 9.

Beck U., 2012, Społeczeństwo światowego ryzyka. W poszukiwaniu utraconego bezpieczeństwa, Wydawnictwo Naukowe Scholar, Warszawa.

Breuer P., 2014, Vorausschauendes Trennungsmanagement - Faktor der Arbeitgeberattraktivitaet in flexiblen Arbeitswelten, [w:] M. Klaffke (red.), Generationen-Management. Konzepte, Instrumente, Good-Practice-Ansaetze, Springer Gabler, Wiesbaden.

Deloitte Global Human Capital Trends 2018, https://www2.deloitte.com/pl/pl/pages/human-capital/ articles/raport-trendy-hr-2018.html (18.11.2018).

Graeber D., 2020, Praca bez sensu, Krytyka Polityczna, Warszawa.

Hausmann V., Williams S.P., 2014, Categorising social media business risks, Fachbereich Informatik, nr 2.

Kehrel A., Kehrel U., 2011, Gefahr erkannt, Gefahr gebannt, Personalwirtschaft, nr 4.

Kobi J.-M., 2002, Personalrisiko-management. Strategien zur Steigerung des People Value, Betriebswirtschaftlicher Verlag, Wiesbaden.

Leung L., Zheng C.P., 2012, Net Generation, [w:] Z. Yan (red.), Encyclopedia of Cyber Behaviour, IGI Global, USA.

Lipka A., 1996, Uwarunkowania komputerowego wspomagania gospodarowania zasobami ludzkimi w przedsiębiorstwie, Wydawnictwo Akademii Ekonomicznej w Katowicach, Katowice.

Lorek E., 2011, Pomiar ryzyka, [w:] Zarzqdzanie zintegrowanym ryzykiem przedsiębiorstw w Polsce, Wolters Kluwer Polska, Warszawa. 
Markowski A., 2019, Kultura języka polskiego. Teoria. Zagadnienia leksykalne, Wydawnictwo Naukowe PWN, Warszawa.

Martin J.E., Heaulme P.-F., 1998, Risk Management: Techniques for Managing Project Risk. Field Guide to Project Management, D.I. Cleland, Van Nostrand Reinhold, New York.

Minchington B., 2018, Employer brand experience. Business models, frameworks and roadmaps to build your strategy, e-publication.

PN-EN ISO 31010:2010, Zarzadzanie ryzykiem - Techniki oceny ryzyka, Polski Komitet Normalizacyjny, Warszawa.

PN-EN ISO 9001:2015, System zarządzania jakościq, Polski Komitet Normalizacyjny, Warszawa.

Verhoeven T., 2019, Digitalisierung im Recruiting, Springer Gabler, Wiesbaden.

Wojtaszczyk K., 2012, Employer branding, czyli zarzqdzanie marka pracodawcy. Uwarunkowania, procesy, pomiar, Wydawnictwo Uniwersytetu Łódzkiego, Łódź.

\section{MEASURING THE RISK OF INCONSISTENCIES IN THE DIGITAL IMAGE OF THE EMPLOYER}

Summary: The paper, of a methodological nature, is oriented towards the purpose of describing the sources and negative effects of inconsistencies in the digital image of the employer. They are then assigned to different types of personnel risk and the way of assessing their level for deficit conditions, and, by comparison, for staffing surplus on the labour market is proposed. D. Baccarini's risk assessment matrix and the methodological proposals of J.E. Martin and P.-F. Heaulme are used. In this way, the answer was found to the research problem formulated in the form of a question: how to measure the level of risk of inconsistencies in the digital image of the employer, taking into account the demand-supply situation in the labour market?

Keywords: risk of inconsistencies, the digital image of the employer, the measurement of personnel risk, the dependence of risk on demand-supply relationships. 